\title{
Beata Popczyk-Szczęsna
}

\section{Tekstualność i teatralność}

ABSTRACT. Popczyk-Szczęsna Beata, Tekstualnośc $i$ teatralnosć [Textuality and theatricality]. „Przestrzenie Teorii" 7, Poznań 2007, Adam Mickiewicz University Press, pp. 187-196. ISBN 978-83-232177-2-5. ISSN 1644-6763.

The book by Patrice Pavis Le thêâtre contemporain. Analyse des textes, de Sarraute à Vinaver comprises the collection of essays on the contemporary French drama. The author proposes the textual analysis, which takes into account all levels of the composition of discourse. The reception of a drama is understood in terms of stage production made by a reader; because in the process of reading he both reproduces the dramatic situation (semantic aspect) and he decodes the situation of expression (stage aspect).

The above mentioned mode of reading may be applied not only to drama. Two texts have been analyzed in the article: the poem Terrorysta, on patrzy (The terrorist, he is watching) by Wisława Szymborska - an example of a lyrical statement constructed in a similar way as the theatrical situation and the drama Terrorysci (Terrorists) by Ireneusz Iredyński - an example of text, which is characterized by the predominance of rhetoric over theatricality. The meaning of these works results from the oscillation between the structure of text and its theatrical potential.

\section{Teoria. Na marginesie rozprawy Patrice'a Pavisa Le théâtre contemporain. Analyse des textes, de Sarraute à Vinaver}

„Kolejność badania współczesnego tekstu winna być następująca: najpierw - tekstualność; potem - budowa dramatu; wreszcie - postaci". Stwierdzenie Patrice'a Pavisa, pochodzące $\mathrm{z}$ artykułu podsumowującego dramaturgię francuską końca XX wieku, zapowiada szereg pomysłów analitycznych dla lektora dramatuํ. Francuski uczony omawia te projekty w książce Le théâtre contemporain. Analyse des textes, de Sarraute à Vinaver, wydanej w Paryżu w 2002 roku².

Pierwsze wrażenia $z$ lektury wspomnianych rozpraw wywołują skojarzenia $\mathrm{z}$ dobrze nam znaną postawą interpretacyjną, proklamowaną przede wszystkim $\mathrm{w}$ artykule $o$ arcyzgrabnym i sugestywnym tytule:

${ }_{1}$ P. Pavis, Przedwczesne podsumowanie, czyli prowizoryczna inwentaryzacja stanu dramaturgii francuskiej na koniec wieku, przel. P. Olkusz, „Dialog” 2001, nr 7.

$2 \mathrm{P}$. Pavis, Le thêatre contemporain. Analyse des textes, de Sarraute à Vinaver. Éditions Nathan, Paris 2002. Fragmenty książki drukowane były w „Didaskaliach”. Por. P. Pavis, „Samotność pól bawelnianych" Bernard-Marie Koltèsa albo świat dealu, thum. M. Borowski, „Didaskalia” 2004, nr 61/62. 
Stuga dwóch panów: dwoisty żywot dramatu ${ }^{3}$. Omawiana przez Pavisa sytuacja sceniczna wpisana w tekst $\mathrm{i}$ idące za tym rozróżnienie: teksty "mocne semantycznie" i teksty "mocne scenicznie" reprezentują styl myślenia o dziele dramatycznym, które skomponowane jest dzięki zespoleniu dwóch porządków - literackiego i teatralnego. Pavis akcentuje wagę skrupulatnej lektury dzieła, lektury uwzględniającej wszelkie poziomy kompozycji dyskursu dramatycznego, zarówno te związane $\mathrm{z}$ organizacją znaków językowych, jak i te odnoszące się do kodowania informacji przeznaczonych dla ewentualnych wykonawców/inscenizatorów tekstu. A zatem, autor koncepcji semiologii zintegrowanej, a także teoretyk inscenizacji, tym razem proponuje czytelnikowi (czytaj także: aktorowi) koncentrację uwagi na dramacie jako tekście. Zacytujmy znowu:

Należałoby opisać figury tekstualne, sprawdzić, jak odnoszą się one do starych i nowych form dramatycznych, a na koniec ustalić, czy działają tu istoty określone psychologicznie, czy też abstrakcyjne aktanty, których aktorzy już nie są wcieleniem. Wbrew wszystkiemu nie należy jednak zapominać, że inaczej niż za czasów Nathalie Sarraute i Becketta postać dramatyczna bynajmniej nie zanika, lecz przeciwnie, wraca do współczesnego pisarstwa scenicznego ${ }^{4}$.

Punktem wyjścia $\mathrm{w}$ tej dramatologii pozostaje zatem struktura wypowiedzi: począwszy od zjawisk fonetycznych, poprzez leksykę, składnię, stylistykę i kompozycję.

Powrót do tekstu to jednocześnie ukłon w stronę retorycznej przeszłości teatru francuskiego; Pavis wspomina o inspiracji dramaturgią klasycyzmu, ale podkreśla też wyraźnie przydatność proponowanej metody w odniesieniu do różnych, zwłaszcza współczesnych dzieł scenicznych. Analiza tekstualna polega na opisywaniu „muzyki i materii słów”, form wypowiedzi, pól semantycznych, gier intertekstualnych, wreszcie znaków literackości (czyli funkcji poetyckiej w rozumieniu Romana Jakobsona). Słowo badane jest $w$ aspekcie semantycznym i fonicznym: jako znak werbalny i dźwięk. Tak drobiazgowa analiza - paradoksalnie wykracza poza niewolnicze przywiązanie do struktury wypowiedzi, bo ułatwia odczytanie "wyobrażonego życia scenicznego" tekstu. Pozwala określić sytuację wypowiadania, wzbogacając tym samym interpretację zarówno podczas lektury czytelnika, jak i lektury inscenizatora.

Sytuacja wypowiadania pozostaje drugim - równie ważnym obok tekstualności - aspektem analizy współczesnego dramatu. Składają się na nią: warunki i determinanty komunikacji, schematy konwersacyjne, rytm, segmentacja i znaki teatralności. Wśród tych ostatnich szczególnie ważną rolę pełni oralny aspekt wypowiedzi. Skupienie uwagi na pau-

${ }^{3}$ D. Ratajczakowa, Sluga dwóch panów: dwoisty żywot dramatu. „Teksty Drugie” 1990, nr 5-6.

4 P. Pavis, Przedwczesne podsumowanie..., op. cit. 
zach, wahaniu, milczeniu, niedopowiedzeniu, na wszelkich błędach językowych lokutorów pomaga skonkretyzować i zinterpretować świat fikcji.

Bazą poszukiwań interpretacyjnych pozostaje zatem tekstualność i teatralnośćs. Ten drugi krąg zagadnień nie jest oczywiście pomysłem nowym. Teatralność tekstu dramatycznego, rozumiana jako „wskazówki dotyczące potencjalnej realizacji scenicznej”, jako „dyspozycja wykonawcza” bądź jako „tekstowe matryce przedstawieniowości”, pojawia się tutaj w kontekście uwag o fakturze wypowiedzi ${ }^{6}$. Tekstualność, nie zaś dramatyczność czy też literackość, jawi się jako podstawowy punkt odniesienia $\mathrm{w}$ refleksji na temat dyskursu dramatycznego.

Koncentracja na tekście, zwłaszcza zaś na tekście najnowszym, stanowiącym wyzwanie dla teatru, prowadzi do odkrycia jeszcze jednego aspektu teatralności. Za Gerdą Poschmann i Hansem Thiesem Lehmanem przypominam, że chodzi o badania „teatralnego potencjału języka"7. Tekst traktowany jest jako kompromis między możliwościami użycia/zestawienia znaków, jako pozornie tylko zastygła i ukończona powierzchnia - pełen napięcia efekt ugody między impulsami, decydującymi o procesie kreacji ${ }^{8}$.

Powyższe, zreferowane pokrótce, założenia wstępu rozprawy Pavisa wywołać mogą lekkie poczucie konfuzji. Cóż bowiem osobliwego odnaleźć można w tej propozycji metodologicznej; jakim wyzwaniem intelektualnym pozostają te pomysły dla czytelnika rozpraw teoretycznych Janusza Deglera, Dobrochny Ratajczakowej, Sławomira Swiontka? Postulat tak skrupulatnej analizy tekstu na pierwszy rzut oka przypomina raczej założenia neo-, a nie poststrukturalizmu. I kolejna wątpliwość, czy podobny kierunek myślenia okazuje się owocny tylko incydentalnie, w odniesieniu do utworów najnowszej dramaturgii francuskiej? Nie zapominajmy przecież, że cytowany Patrice Pavis „pracuje na tekstach” rodzimych, a utwory na przykład Bernarda Marie Koltèsa znakomicie poddają się interpretacjom, akcentującym retoryczne i poetyckie koneksje replik dramatycznych.

5 Por. P. Pavis, Le théâtre contemporain..., op. cit., s. 13.

${ }^{6}$ Por. P. Pavis, Stownik terminów teatralnych, przeł. S. Swiontek, Wrocław 1998, s. $265,545-547$.

7 Por. G. Poschmann, Der nicht mehr dramatische Theatertext: Aktuelle Bühnenstücke und ihre dramaturgische Analyse, Tubingen 1997. Cyt. za: Ch. Balme, Wprowadzenie do nauki o teatrze, przel. W. Dudzik, M. Leyko, Warszawa 2002, s. 106, H.T. Lehmann, Teatr postdramatyczny, przel. D. Sajewska i M. Sugiera, Kraków 2004. Zob. także definicję pojęcia „teatralnosce" w: Stownik dramatu nowoczesnego i najnowszego, red. J.-P. Sarrazac, przeł. M. Borowski, M. Sugiera, Kraków 2007, s. 168.

B Por. uwagi o korekcji w artykule: A. Krajewska, Poznanie dramatyczne, „Przestrzenie Teorii" 2004, nr 3-4. 
Autor książki, świadomy ewentualnych wątpliwości czytelnika, expressis verbis odżegnuje się od postawy logo- i tekstocentrycznej. Skupienie uwagi wokól struktury i kompozycji wypowiedzi traktuje jako element teorii recepcji, zakładającej przywilej wielu możliwych lektur. Propozycja badań tekstualności projektuje aktywną postawę czytelnika. $\mathrm{Z}$ pełną świadomością uwikłania odbiorcy w szereg kontekstów, decydujących o sposobie rozpoznania tekstu. Toteż niebagatelną rolę w modelu analizy Pavisa zajmuje „miejsce odbioru”, metaforycznie mówiąc, punkt orientacyjny, w którym czytelnik uruchamia pytania o temat, fabułę, działania przedstawione i przesłanie tekstu (poziom tematyczny, fabularny, aktancyjny i ideologiczny). Następuje tym samym, jak powiedziałby Roland Barthes, proces mnożenia signifiant. Czytelnik rozpoczyna grę $\mathrm{z}$ tekstem, rozbijając sieć znaków, z których utkany jest ten ostatni, ale rozpoczyna również grę w tekst - jako od-twórca, czyli wykonawca. Tekst funkcjonuje zatem jako między-tekst, odbiorca $\mathrm{z}$ kolei, tak samo jak autor, staje się projektantem znaczeń ${ }^{9}$.

Przywołana w tym miejscu myśl Rolanda Barthes'a znakomicie koresponduje z pomysłami analizy tekstu Patrice'a Pavisa. Cechą znamienną lektury dramatu pozostaje dokonywanie inscenizacji. Odbiorca kreuje sytuację sceniczną we własnej wyobraźni. Interpretuje czytając i widząc; tak przynajmniej powinna wyglądać lektura aktywna. Praca interpretatora oscyluje między odtwarzaniem sytuacji dramatycznej a rozszyfrowywaniem sytuacji wypowiadania, staje wobec wyzwania semantyki i sceniczności. Dzieła bywają „czytelne” i "widzialne”, nie zawsze w równych proporcjach. Dlatego zdarzają się opozycje: słaby tekst mocna scena i vice versa. Teoretycy literatury udowadniają, że niedookreślenia, zawarte immanentnie w każdym utworze, sugestywnie wypełnia lektor. Teoretycy teatru natomiast przekonują, że "niedociągnięcia”, zarówno w sferze czytelności, jak i wizualności przekazu słownego, może wynagrodzić scena ${ }^{10}$.

Tekstualność i wpisana w nią sytuacja wypowiadania decydują zatem o procesie lektury dramatu rozumianej jako „inscenizacja czytelnika". Ten ostatni - w poszukiwaniu znaczenia - konfrontuje sytuację dramatyczną i potencjalną sytuację sceniczną, analogicznie jak odbiorca spektaklu percypuje inscenizację, konfrontując wizualny i tekstowy sposób przedstawiania. Toteż postulat wyodrębniania tekstów mocnych semantycznie i mocnych scenicznie nie ma w swym założeniu żadnego wartościowania, ani tym bardziej klasyfikacji. Pojawia się raczej jako propozycja lektury, możliwość kombinacji i syntetyzowania znaczeń,

${ }^{9}$ Por. R. Barthes, Od dzieła do tekstu, przeł. M.P. Markowski, „Teksty Drugie” 1998, nr 6.

${ }^{10}$ Por. P. Pavis, Od tekstu do przedstawienia: trudny poród, „Dialog” 1989, nr 8. 
stanowiąca strategię gry $\mathrm{z}$ tekstem, zwłaszcza zaś $-\mathrm{z}$ tekstem dramatu. Dodać należy, że nie ma to nic wspólnego z popularną niegdyś opozycją: dramaty sceniczne - dramaty niesceniczne. Dzieje teatru udowodniły, że bezpodstawne są opinie o niesceniczości tekstu. Chodzi raczej o "podatność" utworu na określony trop interpretacji - wykrywanie śladu przewagi „czytelności” bądź „sceniczności”, utrwalonych w tekście jako wyzwanie dla odbiorcy. Podjęcie tropu polega na dookreśleniu i rozbudowaniu śladów, ale istnieje również możliwość ich pominięcia. Nie obowiązują rygorystyczne ramy odbioru. $W$ procesie interpretacji, rozumianym jako nieustanne zmaganie się $\mathrm{z}$ zagrożonym utratą, subiektywnym wymiarem egzystencji, najistotniejsza pozostaje przecież indywidualna perspektywa czytelnika11.

\section{Analiza}

Opozycja mocny - słaby w odniesieniu do relacji między tekstem a sceną ujawnia się nie tylko $\mathrm{w}$ pisarstwie stricte scenicznym. Wskażę poniżej dwa teksty, reprezentujące odrębne rodzaje literackie. Łączy je ten sam temat, a podziały gatunkowe w zaprezentowanym poniżej procesie lektury ulegają raczej polaryzacji niż wiwisekcji. Utwory te to dwa sugestywne przykłady oscylacji między tekstualnością i teatralnością.

W wierszu Terrorysta, on patrzy Wisławy Szymborskiej (z tomu Wiel$k a$ liczba, 1976) dynamizm sytuacji przedstawionej wynika $z$ utrwalenia momentu pełnego napięcia: oto terrorysta przygląda się ludziom, wchodzącym i wychodzącym $\mathrm{z}$ baru - z miejsca, gdzie podłożył ładunek wybuchowy. Nie znamy przyczyn tego działania, nie znamy ideologii, która zainspirowała zbrodnię. Rozpoznajemy tylko upodobanie w obserwowaniu skutków czynienia zła zderzone z nieświadomością zbliżającego się nieszczęścia. Obowiązuje tu wyjątkowo precyzyjny i bezlitosny podział ról: terrorysta jako sprawca igrzyska przygląda się z dystansu, oddzielony pasem bezpieczeństwa oczekuje na wynik swego dzieła. Pozostali bohaterowie: kobieta $w$ żółtej kurtce, mężczyzna w ciemnych okularach, chłopaki w dżinsach, ukazują się jako marionetki skoncentrowane wokół drobiazgowych działań dnia codziennego, nieświadome, że wykonują kroki decydujące o ich życiu. Odbiorca, chcąc nie chcąc, sterowany przez podmiot liryczny, który odlicza upływ czasu, uczestniczy podczas lektury w oczekiwaniu na katastrofę.

Sytuacja liryczna kreowana jest poprzez połączenie dwóch perspektyw. Podmiot liryczny łączy rolę wszechwiedzącego obserwatora z posta-

11 Por. T. Sławek, Tu i tam. Pięć lekcji interpretacji, „Dialog” 2003, nr 5. 
wą zaangażowanego świadka. Z dystansem wprowadza czytelnika in medias res, ukazuje powstanie niewidzialnej relacji, jaka łączy podglądacza i podglądanych. Opisuje działania beznamiętnie, prawie behawioralnie. Z rzadka tylko komentuje zamiary przyszłych ofiar i szczęśliwie ocalonych. Te sporadyczne uwagi ujawniają jednak kłębowisko niewypowiedzianych emocji. Wiele napięcia tkwi w kontraście między krzątaniną ludzi wchodzących i wychodzących $\mathrm{z}$ baru a nieruchomym i skupionym wzrokiem terrorysty. Dynamiczny charakter relacji podkreśla również użycie czasu teraźniejszego i precyzyjne odliczanie upływających minut aż do godziny wybuchu bomby. W tym krótkim tekście zespolone zostały zatem chwyty liryczne, epickie i dramaturgiczne - epicki dystans obserwatora, sugestywność oszczędnej mowy wiązanej oraz napięcie dramatyczne tkwiące w nieuchronności katastrofy.

Szymborska wyznała niegdyś:

Na początku poezja była wszystkim, mową wiązaną wyrażano zarówno uczucia jak i elementarne informacje, począwszy od modlitwy poprzez kodeksy savoir vivre'u i kroniki historyczne po zasady sztuki pisarskiej [...]. Jeśli myślę fabułą, to ją piszę, myślę felietonem, piszę wiersz - felieton. Może w ten sposób wracam niejako do źródeł ${ }^{12}$.

Czytając wiersz Terrorysta, on patrzy, chciałoby się dodać, że Szymborska myśli czasem także dramatem ${ }^{13}$. Tworzy tekst z pomysłu bliskiego kompozycji jednoaktówki fatalistycznej. Kreuje sytuację krańcową, by wskazać absurdalność ludzkich projektów. Zarówno przyziemne zadania zabieganych zjadaczy chleba, jak i karkołomne plany bezlitosnych "naprawiaczy świata" nikną wobec nieprzeniknionych w swej tajemnicy zbiegów okoliczności.

Krótki, choć "mocny semantycznie” tekst, ma jeszcze jedną cechę, która pozwala na interpretację zdarzeń przedstawionych w kontekście teatralnym. Sytuuje lektora $w$ pozycji widza. Wyodrębniony z rzeczywistości fragment ujęty został w ramę, której obrzeża to granice wzroku podglądacza. Percypujemy obraz, będący widokiem, jaki postrzega terrorysta. Zarówno wtedy, gdy obserwuje on potencjalne ofiary, jak i wtedy, gdy (prawdopodobnie) nerwowo spogląda na zegarek. Uczestniczymy w spektaklu, podglądając aktorów i reżysera zdarzeń. Z dojmującym przekonaniem, że ten ostatni nie jest tak naprawdę Reżyserem właściwym. Nie może decydować o wyniku tej roszady, zapowiadającej śmierć. Aktualizację odwiecznej metafory Theatrum Mundi usankcjonować moż-

12 Powrót do źródet. Rozmowa z Wistawq Szymborskq, w: K. Nastulanka, Sami o sobie, Warszawa 1975.

${ }^{13} \mathrm{O}$ podobieństwie niektórych wierszy Szymborskiej do struktury dramatu wspomina Anna Lege ży ńska, Wistawa Szymborska, Poznań 1996, s. 107-114. 
na poprzez odwołanie do innego tekstu poetki. Szymborska napisała przecież o swych wrażeniach $\mathrm{z}$ teatru:

Najważniejszy w tragedii jest dla mnie akt szósty:

zmartwychwstanie z pobojowisk sceny,

poprawianie peruk, szatek,

wyrywanie noża z piersi,

zdejmowanie pętli z szyi,

ustawianie się w rzędzie pomiędzy żywymi

twarzą do publiczności.

Akt szósty to ten „ściskający za gardło" moment, w którym scena zmienia się $\mathrm{w}$ życie. Sytuacja dramatyczna $\mathrm{z}$ wiersza 0 terroryście to zatrzymanie chwili, podczas której to życie zmienia się w scenę. Niestety, tuż przed momentem, kiedy nastąpi prawdziwe, nie tylko udane pobojowisko.

Terrorysta, on patrzy to tekst zaskakujący odbiorcę siłą skojarzeń wizualnych. Jest mocny semantycznie, ale również sugestywny scenicznie, przynajmniej w takim sensie, o którym mówi w swych rozważaniach o tekstach scenicznych Patrice Pavis. Sytuacja liryczna skomponowana została na podobieństwo widowiska, a lektura niezwykle sugestywnie wyzwala "projekty inscenizacyjne”, jakich dokonuje czytelnik w swej wyobraźni. W wierszu czytamy nawet następujący komentarz: „widok jak w kinie". Śmiem jednak twierdzić, że więcej w tym koncepcie podobieństw do sytuacji teatralnej. Sprzyja temu zaprojektowanie sytuacji według zasady tożsamości czasu działań przedstawionych i percypowanych. Można konkretyzować „widok liryczny”, który wzmaga napięcie dzięki zderzeniu dwóch perspektyw: obserwacji podglądanych oczami terrorysty i obserwacji terrorysty jako podglądacza.

Tekst Szymborskiej pozwala na określenie sytuacji lirycznej jako obrazu zadanego do interpretowania. Przypadek zgoła odmienny to tekst, w którym mocna sytuacja dramatyczna ujawnia się przede wszystkim jako sytuacja „czytana”, a nie „wizualizowana”. Przykłładem będą Terroryści Ireneusza Iredyńskiego ${ }^{14}$.

Siła dramatu tkwi w kompozycji wypowiedzi postaci; utwór przypomina dyskurs prezentujący metody pozyskiwania i utrzymywania władzy. Zdarzenia przedstawione to dyskusja na temat zdarzeń, które rozgrywają się w świecie walki politycznej. Gdzieś w Ameryce Srodkowej, w państwie rządzonym przez prezydenta Roblesa, od dłuższego czasu trwa terror ugrupowań opozycyjnych. Rozpoznajemy wydarzenia z punktu widzenia opozycjonistów - akcja toczy się w miejscu ukrycia się członków Ruchu Wyzwolenia. Jak często u Iredyńskego, sytuacja modelowa

14 I. Ired yński, Terroryści, w: tegoż, Dziewięć wieczorów teatralnych, Kraków 1986. 
dominuje nad dramaturgicznym konkretem. Konfrontacja przywódcy, idealisty, kolaboranta i dziennikarki stanowi oś kompozycyjną przekazu, który obnaża brutalność i pazerność jednostek, szermujących hasłami wolności, równości i sprawiedliwości społecznej.

Terroryści to działacze opozycji, ale również buntownicy wobec terroru władzy. Zdarzenia przedstawione stanowią modelową wizję przewrotu politycznego: sugerują prawidłowości krwawej i spektakularnej zamiany miejsc w układzie politycznym. Czas publikacji tekstu - wrzesień 1982 - uruchamia skojarzenia $\mathrm{z}$ kontekstem historycznym. Może dlatego właśnie utwór nie tylko ujawnia pokaz sil w świecie zdeterminowanym przemocą. Stanowi również wypowiedź dramatyczną spod znaku sztuki dyskusji o istocie przełomów politycznych.

Równie ważna jak modelowość zdarzeń, pozostaje retoryczność wypowiedzi postaci. Język jest sprawnym narzędziem w starciu bohaterów, którzy rywalizują między sobą o odkrycie prawdy. Ich prawdy. Obnażenie fałszu i gry pozorów w stanowisku przeciwnika stanowi determinanty zachowań postaci. Akcja dramatu, rozgrywająca się w kryjówce terrorystów, wzmaga oczekiwanie czytelnika na prezentację obrazów przemocy. Okazuje się jednak, że dominantą kompozycyjną tekstu pozostaje jak najbardziej klasyczny chwyt dramaturgiczny: dialog stanowiący wymianę myśli i argumentów. Słowo to oręż w konfrontacji bohaterów: służy prezentacji zmiennych układów sił, pokazuje sprawność w lingwistycznej grze, jaką prowadzą przeciwnicy. Istotniejszy pozostaje sens replik, wskazujący retoryczną moc dialogu, aniżeli ewokowane przez mowę sceniczną skojarzenia wizualne.

O wielkiej roli słowa w starciu bohaterów świadczy chociażby forma aktu II. W przeważającej mierze wypełnia go wywiad dziennikarki Marii Schwartz z przywódcą terrorystów - Numerem 1. To prawdziwy pojedynek werbalny, pokaz sprawności oratorskiej, zmierzający do pokonania przeciwnika. Demonstratywny charakter wypowiedzi żurnalistki lączy elementy popisu i oceny. Dociekliwość zespolona została z niechęcią wobec rozmówcy, pewność siebie z przemożnym pragnieniem zwycięstwa, tzn. obnażeniem fałszu i okrucieństwa ukrytych pod płaszczykiem ideologii wolności.

Maria Schwartz atakuje terrorystę słowami, w których dostrzec można szereg chwytów retorycznych. Przede wszystkim podporządkowuje wywiad regułom amplifikacji. Mnożąc zarzuty, deprecjonuje ideologię Ruchu Wyzwolenia. By pokonać przeciwnika, umiejętnie wydobywa składniki emocjonalne tematu rozmowy. Prowadzi grę na dwóch płaszczyznach: wobec przeciwnika i wobec późniejszych odbiorców wywiadu. Rozpoczyna od argumentu skutecznego dla odbiorcy: od zarzutu wykorzystywania dzieci do walki; kończy argumentem skierowanym do jed- 
nostki - informuje o nieszczęściu, jakie przydarzyło się byłej żonie Numeru 1. Eksponowanie zła, które czynią terroryści, następuje również poprzez takie zabiegi retoryczne, jak opowiadanie i porównanie.

Dziennikarka trafiła na godnego siebie przeciwnika, na taktyka świadomego istoty spotkania, czyli walki dwóch ,ja". Terrorysta rozpoczął spotkanie od gestu zdjęcia maski. Spełnił tym samym prośbę rozmówczyni. To swoiste captatio benvolentiae tylko pozornie stanowi znak pozyskania przychylności i ufności słuchaczki, pozostaje przede wszystkim formą uśpienia jej czujności. Okazuje się podstępem, początkiem gry, której finał to przestroga - założenie karnawałowej maski trupiej czaszki, która zapowiada śmierć dziennikarzy. Sprawność logiczna terrorysty pozwala skutecznie odpierać zarzuty. Numer 1 zaprzecza tezom, podważa sposób myślenia dziennikarki. Kontrargumentuje poprzez odwrócenie kierunku dowodzenia, pomniejsza wagę zarzutów, imputując dziennikarce damską logikę, czyli kierowanie się uczuciami.

Bohaterowie kreują się w tej polemice na orędowników prawdy. W obu przypadkach pozostaje to wyłącznie kamuflażem konwersacyjnym. Retoryczne koneksje dialogu bliższe są kunsztowi prowadzenia sporów aniżeli rozważaniom dialektycznym, które zakładają zbijanie argumentów przeciwnika w celu odkrywania prawdy. Język pozostaje narzędziem prowokacji i dominacji, słowa - formą oszustwa. Te ostatnie funkcjonują często jako znaki bez referencji, przynajmniej dla tego, kto je wypowiada. Podstawowym zadaniem mówiącego pozostaje perswazja i sugestia. Chwyty oratorskie to popisy $\mathrm{z}$ gruntu formalistyczne. W odniesieniu do wypowiedzi bohaterów $\mathrm{z}$ pełnym przekonaniem zacytować można słowa Leibniza:

Retoryka służy tylko do podsuwania fałszywych idei, do podniesienia uczuć i do zwodzenia zdolności sądzenia tak, iż jest to tylko zwykłe mydlenie oczu [...] ludzie bynajmniej nie troszczą się o prawdę, a bardzo lubią zwodzić $i$ być zwodzeni ${ }^{15}$.

Wnioski, jakie płyną z lektury Terrorystów Ireneusza Iredyńskiego, dotyczą zatem nie tylko problemu władzy. Kompozycja wypowiedzi dramatycznej prowokuje do analizy skoncentrowanej na aspekcie tekstualności. To przede wszystkim, jeśli można tak metaforycznie określić, dramat słowa, a nie dramat przestrzeni i ruchu. Istotne dla odbiorcy pozostaje skupienie na strukturze i sensie replik. Wyraźny kontrast między słowem i zamiarem postaci buduje napięcie dramatyczne.

W konfrontacji bohaterów dominuje raczej bezruch, powolność; w relacjach przedstawionych brakuje jawnej walki, ale bezlitosna rywalizacja

15 Cyt. za: M. Korolko, Sztuka retoryki. Przewodnik encyklopedyczny, Warszawa 1998, s. 21. 
werbalna znakomicie ilustruje nienawiść tkwiącą u źródeł decyzji bohaterów. Miejsce akcji, a także stematyzowane fragmenty przestrzeni dramatycznej podkreślają ten typ relacji interpersonalnych. Wydarzenia rozgrywają się w zamkniętych pomieszczeniach. Przedmioty, które wykorzystują lub o których opowiadają bohaterowie, funkcjonują jako rekwizyty maskujące prawdziwe intencje postaci. Sytuacja sceniczna ewokowana słowem wzmaga koncentrację na kompozycji dialogu, pełnego replik w stanie podejrzenia.

\section{Pointa...}

Zestawienie wiersza Szymborskiej z dramatem Iredyńskiego to nie tylko przykład kombinacji badacza tekstu, który dryfuje pomiędzy artefaktami i rozrastającym się wokół nich kłączem informacji/interpretacji16. Utwory te stanowią dobry material do analizy tekstualnej. Wyraźnie pokazują, że tekst "mocny scenicznie” pojawić się może zupełnie niezależnie od jego uwarunkowań gatunkowych, a lektura oparta na kryterium wizualności to nie tylko symptom rozpowszechnionych przyzwyczajeń estetycznych i dominującej „ery voyera”. Z drugiej strony zauważyć można, że dramat, kreujący pełną napięcia sytuację dramatyczną dzięki illokucyjnej mocy słowa, nie zawsze projektuje analizę skoncentrowaną wokół fenomenu teatralności. Co tym bardziej uzasadnia przydatność rozważań nad tekstualnością - jako punktem wyjścia refleksji semantycznej.

Jakie stąd wnioski dla dramatologa?... Przezorność w podpatrywaniu sługi, który rozmaicie traktuje swych panów; wiedzie swawolny, nie tylko „dwoisty żywot”. Choć nie podważa to zasady, że czytelnik ma prawo projektować zdarzenia przedstawione jako wypowiedziane na scenie, a lektura polegać może na rozpoznawaniu „wyobrażonego życia scenicznego" tekstu.

Oczywiście, zaprezentowane powyżej refleksje to tylko przykład-fragment rozważań, powstałych na marginesie rozprawy Patrice'a Pavisa. Projekt analizy tekstualnej wydaje się inspirującym pomysłem, zarówno w badaniach dramatu, jak i teatru postdramatycznego. Podkreśla bowiem możliwość spojrzenia na tekst teatralny jak na dynamiczną teksturę znaczącą, otwartą, bo sprzyjającą różnorodnej percepcji potencjalnego odbiorcy-,wykonawcy” dramatu, czyli i aktora, i lektora, i widza.

16 Por. W. Kuligowski, O przyjemności analogii, w: Antropologiczne wędrówki po kulturze, red. W. Burszta, Poznań 1996. 